\title{
Preface - Human-altered coastal systems: processes, monitoring, and management
}

\author{
Edward J. Anthony • Norbert P. Psuty
}

Published online: 26 June 2014

(C) Springer Science+Business Media Dordrecht 2014

The imperatives of economic development have constantly brought pressure to bear on coasts. In many countries throughout the world, the coast is increasingly destabilized by the construction of tourist infrastructure, routes, and harbours. The lessons accumulated from the destabilization of coasts by massive development, commonly resulting in erosion and costly mitigation solutions, are commonly forgotten or deliberately ignored under the pressures of development. At the same time, increasing human occupation of the coastal zone is resulting in alterations of the coast and aggravating exposure of coastal communities to risks arising from high-energy events, global change, and sea-level rise. This special issue of the Journal of Coastal Conservation and Management brings together experiences on human-altered coasts, through case studies, from several countries, that illustrate links between the physical and human dimensions of coasts that subtend the objectives and activities of the Commission on Coastal Systems (CCS) of the International Geographical Union (IGU). The eight papers in this special issue represent a cross-section of the oral presentations contributed under the banner of the CCS at the IGU conference held in Cologne, Germany, in August 2012. The papers address various aspects of coasts. The importance of a good grasp of the morphodynamic functioning of beaches and dunes prior to forms of management is brought out in the paper by Sedrati and Anthony (2013). The paper by van der Meulen et al.

\section{E. J. Anthony $(\square)$}

Aix-Marseille Université, Institut Universitaire de France, CEREGE UMR 34, Europôle de l'Arbois, 13545 Aix en Provence Cedex,

France

e-mail: anthony@cerege.fr

\section{N. P. Psuty}

Sandy Hook Cooperative Research Programs, Institute of Marine and Coastal Sciences, Rutgers University Highlands, 74 Magruder Road, Highlands, NJ 07732-4054, USA

e-mail: psuty@marine.rutgers.edu
(2014) is a good illustration of how coastal defence can work with nature through dune-building, whereas Tresca et al. (2013) propose an interesting case study of dune growth and dynamics on a seawall. The utility of a sediment budget approach in beach management is brought out in the paper by Psuty et al. (2013). Chadenas et al. (2013) and Musereau and Regnauld (2014) propose studies that highlight the impacts of storms and, the former brings out, in particular, the lessons from the devastating 2010 superstorm Xynthia. Harley et al. (2013) propose a case study of the utility of coastal video monitoring in analysing nourishment and morphological changes on a gravel beach, and Jeanson et al. (2013) show the various stages of building up a GIS-based coastal observation network and its utility in hazard monitoring. Finally, Brooks and Spencer (2013) has documented the decadal-scale patterns of retreat of soft cliffs. It is intended that the papers will contribute to the corpus of research on human-altered coasts and to ways of mitigating coastal destabilization, in line with the objectives of the Journal of Coastal Conservation and Management.

\section{References}

Brooks SM, Spencer T (2013) Importance of decadal scale variability in shoreline response: examples from soft rock cliffs, east Anglian coast, UK. J Coast Conserv. doi:10.1007/s11852-013-0279-7

Chadenas C, Creach A, Mercier D (2013) The impact of storm Xynthia in 2010 on coastal flood prevention policy in France. J Coast Conserv. doi: $10.1007 / \mathrm{s} 11852-013-0299-3$

Harley MD, Andriolo U, Armaroli C et al (2013) Shoreline rotation and response to nourishment of a gravel embayed beach using a low-cost video monitoring technique: San Michele-Sassi Neri, central Italy. J Coast Conserv. doi:10. 1007/s11852-013-0292-x

Jeanson M, Dolique F, Anthony EJ (2013) A GIS-based coastal monitoring and surveillance observatory on tropical islands exposed to climate change and extreme events: the example 
of Mayotte island, Indian ocean. J Coast Conserv. doi:10. 1007/s11852-013-0286-8

Musereau J, Regnauld H (2014) Storms impact on morphodynamics of human controlled coastal features in western France: the prevailing role of local management practices. J Coast Conserv. doi:10.1007/ s11852-014-0311-6

Psuty NP, Spahn A, Silveira TM et al (2013) Sediment budget as a driver for sediment management at plumb beach, New York, USA: vectors of change and impacts. J Coast Conserv. doi:10.1007/s11852-0130293-9
Sedrati M, Anthony EJ (2013) Confronting coastal morphodynamics with counter-erosion engineering: the emblematic case of Wissant Bay, dover strait. J Coast Conserv. doi:10.1007/s11852-013-0300-1

Tresca A, Ruz M-H, Grégoire P (2013) Coastal dune development and sand drifting management along an artificial shoreline: the case of Dunkirk harbour, northern France. J Coast Conserv. doi:10.1007/ s11852-013-0302-z

van der Meulen F, van der Valk B, Baars L et al (2014) Development of new dunes in the Dutch delta: nature compensation and 'building with nature'. J Coast Conserv. doi:10.1007/s11852-014-0315-2 